\title{
Acercamientos teóricos al problema de la percepción y escritura de imágenes: el montaje como procedimiento
}

\section{Theoretical approaches to the issue of Perception and Writing Images: Montage as procedure}

\author{
Victoria CÓCCARO \\ Universidad de Buenos Aires \\ victoriacoc@gmail.com
}

Recibido: 06-06-2012

Aceptado: 18-12-2012

\section{Resumen}

Desde principios del siglo XX la percepción opera por montaje de manera creativa. Como en un aleph, todo resulta infinitos centros de información que provocan distintas versiones a través de sus posibles relaciones: percibir es crear un montaje de elementos heterogéneos. «El Aleph» de Borges funciona como un ejemplo de problematización de algunas teorías de la imagen desarrolladas en el siglo XX que nos interesan tratar aquí, y donde también pueden apreciarse dos formas de montaje: sintagmático y paradigmático, acercando la palabra ora al discurso, ora a la imagen. Daneri y Borges, dos formas de escribir imágenes ¿Cómo arma, cada uno, el montaje de su escritura del Aleph?

Palabras clave: imagen, escritura, montaje, experiencia, percepción.

Abstract

Since the early 20th century, perception works by montage in a creative way. Like in alephs, everything has infinite centres of information which trigger various and different interpretations through their possible relations: perceiving is to create 
a montage of heterogeneus elements. In Borges' «Aleph» several image theories developed in the $20^{\text {th }}$ century are questioned and also two ways of montage - sintagmatic and paradigmatic - are displayed, approaching words either to speech or to image. Daneri and Borges, two ways of writing images, how does each one of them set the montage of their own writing of the «Aleph»?

Keywords: Image, writing, montage, experience, perception.

\section{Introducción}

...noté que las carteleras de fierro de la Plaza Constitución habían renovado no sé qué aviso de cigarrillos rubios; el hecho me dolió, pues comprendí que el incesante y vasto universo ya se apartaba de ella y que ese cambio era el primero de una serie infinita. ${ }^{1}$

De nuevo aguardaría en el crepúsculo de la abarrotada salita, de nuevo estudiaría las circunstancias de sus muchos retratos. Beatriz Viterbo, de perfil, en colores; Beatriz con antifaz, en los carnavales de 1921; la primera comunión de Beatriz; Beatriz, el día de su boda con Roberto Alessandri; Beatriz, poco después del divorcio, en un almuerzo del Club Hípico; Beatriz en Quilmes, con Delia San Marco Porcel y Carlos Argentino; Beatriz, de frente y de tres cuartos, sonriendo, la mano en el mentón....2

Ya en las primeras páginas de «El Aleph» aparecen dos modos distintos de percepción de imágenes y que, a su vez, se insertan en la escritura de maneras distintas. Estos dos momentos se corresponden con dos líneas de fuerza que el relato alberga en cuanto "imágenes escritas", encarnadas por distintos personajes. Los problemas teóricos que en principio quiero desarrollar son el de la relación entre imagen y escritura, las formas de tratar imágenes en la escritura, en el marco de la percepción de imágenes. De acuerdo a esto, parto de la base de pensar a la escritura como montaje, tal como comenta Shklovski en su libro sobre Eisenstein, "una mayúscula es la huella de un montaje, la separación entre un pensamiento y otro"3; y del mismo modo puede considerarse a la percepción si es que conoce al mundo dividiéndolo, pues "seleccionamos lo que vemos"4.

Entonces, en primer lugar, ¿cómo aparece el montaje en la escritura? Como en el cine, puede ser funcional al desarrollo del "tema" o intervenir activamente en la construcción alterando lo "unilineal" de un "desarrollo clásico". Es decir, hay narrativa "que muestra honradamente lo que está sucediendo" 5 donde el montaje funcio-

\footnotetext{
${ }^{1}$ Borges, J.L., "El Aleph”, El Aleph, Buenos Aires, Emecé, 2000, p. 241.

2 Ibidem, p. 242.

3 Shklovski, V., Eisenstein, La Habana, ICAIC, 2009, p. 153.

4 Ibidem, p. 84.
} 
na como sucesión y adición (el +1 sobre la línea recta), y el orden de los hechos se acomoda en función de desarrollar el argumento (en el sentido de "intriga", "fábula"). Por otro lado, el montaje puede funcionar y aparecer como una simultaneidad sin un obligado orden de continuación y desarrollo, donde se da una coexistencia no diacrónica ni unilineal de lo presentado, y el sentido surge, en todo caso, por esa coexistencia y tensión, y no por una lógica de causas y efectos. En este último caso considero que el montaje aparece como un nuevo elemento y como una nueva posibilidad. Cada uno de estos tratamientos acercan más la palabra a su propio orden, el discurso, donde la palabra transcurre en el tiempo, (¿insertada en el devenir temporal de los cambios de los afiches publicitarios?), o bien, más hacia el orden de la imagen, ya que "la imagen visual es instantánea. Como un fantasma, aparece en un encuadre minúsculo y el tiempo es irrelevante”6, (¿como con Beatriz?).

En segundo lugar, quisiera repasar tan solo dos teorías sobre percepción de imágenes elaboradas en la primera mitad del siglo XX. Shklovski señala las velocidades, la variación en los espectáculos y en el modo de ver, pensar y sentir, como el cambio en la percepción que ocurre a principio de siglo. A su vez, Benjamin advierte en 1936 la relación entre el cine y las modificaciones en el aparato perceptivo ${ }^{7}$. En su conocido texto «La obra de arte en la era de la reproductibilidad técnica», Benjamin escribe sobre las condiciones de producción de las obras (su reproductibilidad) pero lo crucial, en su análisis, ¿no se juega en la percepción? Es decir, que su método, a saber, materialismo marxista de tipo redencionista, le exige tomar como punto de partida las condiciones materiales que tienen como efecto un cambio en el modo en el que se perciben las obras, pero queda como interrogante, de todos modos, un título que habla de las condiciones y un texto que desarrolla los efectos de las condiciones. El escrito comienza con el presupuesto: "dentro de los grandes espacios históricos de tiempo se modifican, junto con toda la existencia de las colectividades humanas, el modo y manera de su percepción sensorial"8. Allí el análisis material de la obra de arte se hace desde el punto de vista del lector, del público, del receptor; al igual que en su «Pequeña historia de la fotografía» advierte el cambio en la condición de la mirada (desde la reproductibilidad técnica), es decir una alteración en la percepción. En esta línea, entonces, también es pensado el concepto de aura que "como la manifestación irrepetible de una lejanía no representa otra cosa que la formulación del valor cultual de la obra artística en categorí-

\footnotetext{
5 Ibidem, p. 215.

6 Ibidem, p. 154 (ambas citas).

7 "La recepción en la dispersión, que se hace notar con insistencia creciente en todos los terrenos del arte y que es el síntoma de modificaciones de hondo alcance en la apercepción, tiene en el cine su instrumento de entretenimiento" (Benjamin, W., «La obra de arte en la época de su reproductibilidad técnica», en Discursos Interrumpidos [trad. de Jesús Aguirre], Barcelona, Planeta-Agostini. 1994, p.54.) 8 Ibidem, p. 23.
} 
as de percepción espacio temporal"9. La percepción es un tema central de la teoría benjamineana, donde modificada y entrenada por la reproductibilidad técnica 10 , resulta distraída, dispersa, contraria a la atención detallada, atenta y singular exigida por el arte anterior: "comparemos el lienzo (pantalla) sobre el que se desarrolla una película con el lienzo en el que se encuentra una pintura. Este último invita a la contemplación; ante él podemos abandonarnos al fluir de nuestras asociaciones de ideas. No podremos hacerlo ante un plano cinematográfico. Apenas lo hemos registrado con los ojos ya ha cambiado"11. La percepción en la dispersión como uno de los rasgos de la experiencia moderna que caracteriza al flaneur benjamineano, habilita el deleite analítico de lo efímero "mientras recorre -sin rumbo fijo, los sentidos alerta- el laberinto de calles y barrios, enterándose de "lo que ha sido" a partir de los estilos de edificación..."12. Es decir, una percepción dispersa de lo dado por montaje paradigmático (y una percepción entrada en la era de la reproductibilidad técnica lo hace) puede ser una forma de conocimiento (por ejemplo, un conocimiento dialéctico que descubre el pasado y el futuro en el presente, una percepción de lo simultáneo a través de las relaciones que el montaje establece entre los elementos). En síntesis, ambos autores sugieren que un cambio en la percepción sensorial, producido por cambios históricos que son encarnados por las obras de arte, generan, a su vez, nuevos modos creativos, sea en la escritura, sea en el cine.

\section{Las imágenes. Percepción y escritura}

A partir de los escritos de Benjamin y Shklovski, ¿qué teorías de la percepción y de la escritura de imágenes aparecen en «El Aleph»? En la primera oración del cuento se habla sobre "no sé qué aviso de cigarrillos rubios" en la Plaza Constitución, una imagen construida desde lo que Benjamin llamó una percepción no ritual de un objeto sin aura (acrecentada por la proliferación de imágenes de la publicidad en la cultura de masas, etc.). En una experiencia subconsciente, esta pasa

\footnotetext{
9 Ibidem, p. 26.

10 "Tanto en el mundo óptico como en el acústico, el cine ha traído consigo una profundización similar de nuestra apercepción" (Ibidem, p.46). "La reproductibilidad técnica de la obra de arte modifica la relación de la masa para con el arte" (Ibidem, p.44). "La recepción en la dispersión está condicionada, sobre todo, por la dinámica de la tecnología moderna, por la tecnologización de las cosas -el ritmo de vida acelerado, las rápidas transiciones de los medios modernos, la presión de las mercancías y su obsolescencia programada, etcétera" (Ibidem, pp. 59-60). "La teoría de la dispersión de Benjamin que es también una teoría de la percepción, el papel fundamental desempeñado por el cine en acostumbrar a «las masas» a esta nueva modalidad de experiencia" (Eiland H., «Recepción en la dispersión», Walter Benjamin: Culturas de la imagen, Buenos Aires, Eterna Cadencia, 2010, p.63).

11 Benjamin 1994, op. cit. (nota 7), p. 51.

12 Eiland 2010, op. cit. (nota 10), p. 67.
} 
por la conciencia sin dejar huella, no se recuerda el detalle de la imagen... no sabemos qué. Caracterizada por la velocidad de su paso inadvertido, esta imagen aparece insertada en un "montaje sintagmático", horizontal, donde el devenir temporal se dibujaría como una línea en avance continuo e incesante. Es decir, Borges inserta esta imagen en una serie diacrónica y sucesiva, la cual reaparecerá más adelante con la noticia de la demolición de la casa de Beatriz: "todo cambio es un símbolo detestable del pasaje del tiempo". El avance del tiempo y los cambios materiales como testimonio del robo del tiempo sobre la vida es uno de los rasgos de la experiencia moderna apuntada por Baudelaire: "el tiempo come la vida"13, dice uno de sus versos. Por otro lado, luego de esta imagen en la vía pública, fugaz e inadvertida, nos encontramos frente a los retratos de Beatriz Viterbo que son percibidos con devoción y detenimiento. No casualmente son parte de un ritual que se cumple cada año (y diariamente, "muerta podía entregarme a su memoria"), en el que lleva las ofrendas correspondientes (libros, alfajores santafecinos, coñacs del país). Además son descritos con un ritmo cultual de "rezo", letanía, un ritmo que repite el nombre de Beatriz y halla su devoción en esta repetición encadenada de su nombre, como se muestra en la cita de la primera página. Devoción por su nombre que volverá a aparecer: “... hablar con Álvaro y decirle que el primo hermano aquel de Beatriz (ese eufemismo explicativo me permitiría nombrarla)"; y por tercera vez en otro encuentro con el gran retrato intemporal de Beatriz, situación íntima de encuentro con el amado ("no podía vernos nadie"), "Borges", el narrador, "le habla" y repite su nombre cinco veces. Las fotografías de Beatriz son presentadas auráticamente a pesar de tratarse de productos reproductibles, pues es en el retrato donde radica, para Benjamin, el último valor cultual de la imagen fotográfica:

En la fotografía el valor exhibitivo comienza a reprimir en toda la línea el valor cultual. Pero este no cede sin resistencia. Ocupa una última trinchera que es el rostro humano. En modo alguno es casual que en los albores de la fotografía el retrato ocupe un puesto central. El valor cultual de la imagen tiene su último refugio en el culto al recuerdo de los seres queridos, lejanos o desaparecidos. ${ }^{14}$

En esta contradicción que encierran los retratos (objetos reproducibles con valor cultual) se adhiere otra, la percepción educada por la técnica (y por la reproductibilidad técnica) ofrece una imagen simultánea y fragmentada, pero no por eso pierde valor cultual15. En esta segunda aparición de imagen en el texto, a diferencia del afi-

13 “-¡Oh dolor!, ¡oh dolor! El tiempo come la vida, / y el oscuro Enemigo que nos corroe el corazón / crece y se hace fuerte con la sangre que perdemos" (Baudelaire, Ch., «El enemigo», en Las flores del mal [trad. de Américo Cristófalo], Buenos Aires, Colihue, 2006, p. 35).

14 Benjamin, W., «Pequeña Historia de la Fotografía», en Discursos Ininterrumpidos I (trad. de Jesús Aguirre), Madrid, Taurus, 1987, p.31.

15 Esta ambigüedad y vaivén de los conceptos en Benjamin ha sido certeramente apuntado por Eiland: la dispersión no sólo es lo contrario a concentración. Asimismo Beatriz es cada vez "la manifestación 
che de Constitución donde predomina lo que Benjamin llama el valor exhibitivo de la imagen, los retratos de Beatriz se introducen por montaje paradigmático, como la primera plana de un diario que ofrece numerosos y distintos centros de información (como el Aleph tiene muchos centros sin circunferencia). De los retratos -a diferencia del olvidado afiche- se advierten y nombran algunos detalles detenidamente, observados con lentitud. Este es su Aleph, conjunto de retratos percibidos como cuadro cubista (“... de perfil, en colores; (...) de frente y de tres cuartos"), estética en la cual Benjamin advierte, aunque insuficientemente, "la imbricación de la realidad y los aparatos"16. ¿En qué orden se ve un cuadro donde hay escritura? y ¿en qué orden se lee una escritura donde hay cuadro? El cubismo nos ofrece pensar ambas posibilidades, cuadros que incluyen fragmentos de diarios (por nombrar solo dos: Naturaleza muerta sobre silla de rejilla, 1912, de Picasso o Le Journal, 1916, de Juan Gris), y, por ejemplo, el modo de presentación cubista de la imagen en la escritura de este fragmento de «El Aleph» 17.

Detengámonos por un momento en esta escena para advertir el modo en que son percibidas y puestas en escritura las fotografías de Beatriz. Las reflexiones de Barthes sobre la fotografía nos ayudan a pensar este modo de percepción de imágenes que son retenidas en la memoria con un movimiento contrario al de las imágenes que cambian avanzando con el tiempo que come la vida, aquí las fotografías le roban algo al robo del tiempo... Esos azarosos detalles ("ese azar que en ella me despunta"18) percibidos (la sonrisa, la mano en el mentón) son parte de la importancia que se otorga, en esta escena ritual, al poder de la fotografía a través de eso que lastima y punza, por un observador asaltado por una desesperación de ternura. Borges, al ver los retratos se propone estudiar las circunstancias de los detalles, esa verdad enfática del gesto de la que habla Barthes en su teoría sobre la fotografía. De esta teoría quisiera rescatar el pasaje del sujeto fotografiado a objeto al convertirse en Todo-Imagen, pues es importante advertir cómo Beatriz no es sino esas fotografías. Es decir, las fotos no son apariciones de "lo sido", ya que las imágenes no son tratadas aquí como referencias a lo vivo (muerto). Tanto la imagen como la palabra (el

irrepetible de una lejanía", pero también reúne las características de los objetos sin aura, el deseo de adueñarse de ellos en la imagen y su devenir imagen fetichizada.

16 Ibidem, p. 42

17 "En los cuadros cubistas, desaparece la perspectiva tradicional. Trata las formas de la naturaleza por medio de figuras geométricas, fragmentando líneas y superficies. Se adopta así la llamada «perspectiva múltiple»: se representan todas las partes de un objeto en un mismo plano. La representación del mundo pasa a no tener ningún compromiso con la apariencia de las cosas desde un punto de vista determinado. Por eso aparecían al mismo tiempo y en el mismo plano vistas diversas del objeto: por ejemplo, se representa de frente y de perfil; en un rostro humano, la nariz está de perfil y el ojo de frente; una botella aparece en su corte vertical y su corte horizontal. Ya no existe un punto de vista único. No hay sensación de profundidad”. Ramírez Domínguez, J. A., «El cubismo», en Historia del Arte, Madrid, Anaya, 1986, pp. 776-784.

18 Barthes, R., La cámara lúcida: nota sobre la fotografía, Buenos Aires, Paidós, 2004, p. 59. 
nombre de Beatriz, que por cierto pierde sentido en la repetición) no son evocativas, pues Beatriz ES esas palabras (su nombre) y esas imágenes ${ }^{19}$, no se relacionan con momentos vividos, no redimen ni reviven. La imagen y la palabra (que toma algo de la imagen, cierta contingencia, cierto particular) no rebasan su aparición. Es eso, esto. Por eso Borges mira entregado a esa especie de retrato cubista de Beatriz, primer Aleph del cuento (su propio y amoroso Aleph), ahora que ella ha muerto Borges puede entregarse a lo que ama en verdad: la imagen de Beatriz. Como Orfeo en busca de su Eurídice en el inframundo, Borges tiene los retratos de Beatriz (no la Eurídice ni la Beatriz diurna de la vida sino solo la imagen y la palabra "Beatriz"), en ambos el deseo de la amada no es tanto de su presencia como de su imagen, su amada es su imagen y el canto que la nombra.

He dicho que el conjunto de retratos aparece reordenado por el narrador, la imagen de Beatriz está procesada, recifrada, montada, ¿ese montaje nos acerca o nos aleja de Beatriz? Beatriz es esas imágenes rejuntadas, toman su valor en lo mostrativo de esa escritura. El modo de ser de Beatriz es esta percepción y escritura de Borges. Didi-Huberman, aunque desde un análisis con implicancias históricas y políticas sobre Brecht, hace posible advertir el procesamiento necesario ante la imagen para poder "saber" algo de ella. Sostiene, desde lo que podríamos llamar una política de la forma, que el modo de mirar es toma de posición y acto político, donde el montaje (utilizado activamente como procedimiento decisivo y constructivo) es indispensable. El enfoque, la toma de posición -que es exposición- es "saber" y forma, es decir, el montaje es forma de conocimiento. Más allá del lúcido análisis sobre Brecht, Didi-Huberman nos permite rescatar el antecedente dadaísta de cortar y pegar el periódico como un descomponer ese "dar forma" falsificado de los informativos, a través de su recomposición y remontaje, por ejemplo con la técnica de fotomontaje. "No hay otra objetividad que una objetividad artística"20, Brecht es rescatado como escrutador, recortador y recopilador de la información que le ofrecían los periódicos en el exilio. Nuevamente, el modo de percepción crea al objeto, o más bien, el modo de operar con él a través del montaje hace conocerlo, ver es saber (pero hay que saber ver ${ }^{21}$ ) insiste Didi-Huberman; generar su visión no su reconocimiento, decía Shklovski. Sobre el Arbeitsjournal de Brecht se seña-

19 Imagen y palabra: "me aproximé al retrato y le dije: Beatriz, Beatriz Elena, Beatriz Elena Viterbo..." (Borges 2000, op. cit. (nota 1), p. 256.

20 Didi-Huberman, G., «La posición del exiliado: exponer la guerra», en Cuando las imágenes toman posición. El ojo de la historia, 1, Madrid, A. Machado Libros, 2008, p. 21.

21 "Nadie sabe mirar, no es algo dado. Mirar es un trabajo, largo y duro. Cada imagen nueva requiere un trabajo nuevo, reaprender a ver y a hablar. Hay que respetar que las cosas aparecen siempre de manera diferente y verlas de manera cada vez diferente. Para describir cada nueva imagen hay que tener cada vez un estilo diferente. Si tienes el mismo estilo para describir imágenes distintas, ves de la misma manera cosas diferentes”. (Didi-Huberman, G., «Las imágenes son un espacio de lucha», entrevista con Amador Fernández-Savater disponible en http://drogoliticas.blogspot.com, 2010. 
la que "es un diario donde se construyen juntas aunque sea para contradecirse, todas las dimensiones del pensamiento brechtiano"22, algo así como el Aleph de su pensamiento: el diario de Brecht multiplica los puntos de vista como en la pintura china (el Aleph muestra todo desde todos los puntos de vista), y en su forma se acerca menos a la crónica de los días que transcurren (diacrónica, sucesiva y sintagmática) que a una sala de montaje. Este modo de acercarse a la historia no responde a la narración cronológica ${ }^{23}$, ni a una teleología, más bien la escritura toma una potencia visual. La experiencia como inscripción (en vez de representación) de un sujeto aparece por recortes: "no se puede pedir demasiado al psicoanálisis como tampoco se puede pedir demasiado a la imagen; basta con los fragmentos, con los pequeños momentos"24. Dice Shklovski que "la biografía de un hombre no se compone de los momentos que se suceden uno a uno. La biografía se niega a sí misma"25, asimismo Didi-Huberman recuerda el Diario de Kafka como montaje de notas y pensamientos, esbozos e imágenes. Es decir, pueden definirse al menos dos modos de trabajar la imagen en la escritura, como dos modos de percepción que generan escrituras distintas: respondiendo al valor discursivo, deductivo o demostrativo de la exposición -cuando exponer significa explicar, elucidar, contar en el orden justo-, o desplegando su valor icónico, tabular y mostrativo.

En este espacio de simultaneidades, más ligado al montaje paradigmático que a un montaje sintagmático, está no tanto el recuerdo si no Beatriz misma. ¿Cómo pensar este espacio de simultaneidades? En este punto me acerco a otra teoría de la imagen propuesta por la obra mnemosyne del artista alemán Aby Warburg que DidiHuberman ha vuelto a poner en el centro de atención. Esta obra, una especie de mapa de la historia, un atlas, o mejor, una especie de Aleph donde entra todo a través del vínculo, es un buen ejemplo para pensar al montaje paradigmático ya que es - podríamos decir- el corazón de la obra, una especie de red donde nada se simplifica sino que todo se ramifica: tiempo y espacio de relectura y cita constante. El enlace de las imágenes no se da de manera lineal y sintagmática sino de forma ramificada, paradigmática. En base a esta propuesta, Didi-Huberman se niega a la idea de hacer una "línea de tiempo" y propone abrazar la multiplicidad y tratar de entender la historia desde el despliegue y el vínculo, porque de esa manera está en el pensamiento y en el arte, como una condensación del todo en cada parte.

\footnotetext{
22 Didi-Huberman 2008, op. cit. (nota 22), p. 23.

23 "Esto remite evidentemente a ciertas empresas literarias que Brecht conocía desde los años veinte, tales como Nadja de Andre Bretón o, más cercano al escritor alemán, Berlin Alexanderplatz de Alfred Doblin, sobre el que Walter Benjamin había analizado la "crisis de la novela» en términos que desembocaban en la defensa de una escritura del montaje documental" (Ibidem, p. 32).

24 Ibidem, p. 1.

25 Shklovski 2009, op. cit. (nota 3), p. 76.
} 
Hay en «El Aleph» una "confianza" en la imagen (la existencia de Beatriz como imágenes, el Aleph permite ver lo que el ojo no puede ver), la consideración de una verdad que dan las fotos 26 que está en línea con los escritos bartheseanos ("la fotografía me permite el acceso a un infra-saber" 27 ) y las observaciones benjamineanas de la foto como contemplación que supera a la realidad 28 . Si contemplar el mundo es contemplar imágenes, no hay contraposición entre experiencia e imágenes. Las imágenes en el Aleph no son cuestionadas en sí, el problema es otro: cómo hablar de ellas, cómo escribir.

Tengo una experiencia que se repite. Estoy en un museo o donde sea y me encuentro con una imagen que me interesa. $\mathrm{Y}$ en ese momento no tengo nada que decir, no hallo las palabras, soy incapaz de lenguaje, es un momento de silencio, la imagen tiene el poder de privarme de mi lenguaje. Si me quedo ahí me convertiré en un místico de las imágenes, como hay muchos. Pero para mí el desafío es que la imagen me obligue a renovar mi lenguaje. Naturalmente, ese lenguaje renovado será crítico con respecto al primer lenguaje espontáneo ante la imagen. 29

El problema de la imagen se desplaza a las formas de sus relaciones, la forma de poder hablar de ellas como un trabajo de montaje. Entonces: cómo "contar" la imagen, cómo escribir la imagen, cómo darle lugar a la renovación que opera en mi lenguaje; qué relación hay entre la imagen y la palabra, cómo puede usarse el procedimiento del montaje en una como en otra, cuándo la palabra se convierte en imagen, cuándo es más imagen que palabra, cómo existe la imagen fuera de la palabra, cómo la palabra puede salirse de la palabra. Y, nuevamente, qué tratamiento se da a la imagen usada para representar (y repetir lo obvio) o para fabricar algo nuevo, un conocimiento transversal, no estandarizado, de nuestro mundo. La repetición del estereotipo, el cigarrillo rubio, los versos de Daneri, o la visión-creación de Beatriz en su montaje de fragmentos y otra forma de exponer el Aleph.

\footnotetext{
26 El Aleph como fotografía: pone al alcance del ojo lo que el ojo no ve ni puede ver ("lo que ocurre entre la mano y el metal" al agarrar una cuchara), juega la oscuridad y la luz (el sótano y todas las luminarias), verlo es revelar fotografías ("el niño estaba, como siempre, en el sótano, revelando fotografías"), exige un tipo de percepción (la oscuridad, la inmovilidad (versus la movilidad de Constitución), cierta acomodación ocular, un confuso malestar.

27 Barthes 2004, op. cit. (nota 19), p. 62.

28 Lo cual puede verse en el concepto de inconsciente óptico. "En una ampliación no solo se trata de aclarar lo que de otra manera no se vería claro, sino que también aparecen en ella formaciones estructurales del todo nuevas. Y tampoco el retardador se limita a aportar temas conocidos del movimiento, sino que en estos descubre otros enteramente desconocidos (...) La naturaleza que habla a la cáara no es la misma que la que habla al ojo" (Benjamin 1987, op. cit. [nota 15], p. 48). Hay en Benjamin una confianza en la relación entre la imagen y lo real pero está también toda la crítica de la imagen tal y como es utilizada. Ambigüedad y tensión que encierra su pensamiento en general.
}

29 Didi-Huberman 2010, op. cit. (nota 23). 


\section{Daneri y Borges, ante el Aleph}

Al comienzo cité a Shklovski para pensar a la escritura como montaje y también para demostrar al menos dos posibilidades de armar ese montaje: por un lado, lo que llamé "narrativo", extenso, sintagmático, diacrónico, por sucesión temporal y aditiva -lo cual responde al orden de las palabras en el discurso-; por el otro, uno sincrónico, pluricéntrico y cubista. Para perseguir en el resto del cuento estas posibilidades, consideraré a los dos personajes que se encuentran y enfrentan, Carlos Argentino Daneri y "Borges". Son los únicos dos personajes que tienen la experiencia del Aleph, y la escriben. Imagen, percepción y escritura. ¿Qué posición toman ante el problema de escribir imágenes? ¿Cómo toman posición ante el Aleph?

No había de un lado el relato de los hechos y del otro la explicación filosófica o científica que descubriese la razón de la historia o la verdad escondida tras ella. No había por un lado los hechos y por otro su interpretación. Había dos maneras de contar una historia. ${ }^{30}$

Del Aleph de Daneri leemos los versos y sus explicaciones, Daneri lee y dictamina; el Aleph de Borges aparece, al contrario, en y por la escena de contemplación. Podríamos decir, entonces, uno aparece representado, contado después de su visión y repetido por segunda vez (en la lectura de Daneri de su escritura del poema), y además explicado y repetido por tercera vez, en un intento de definir su modo de lectura, cierta verdad en las palabras, eso que "quiso decir"; el otro es solo - y es mucho- efecto de superficie de presentación de la escena de contemplación, única enumeración. Daneri explica, sobrexpone el Aleph, y así en su afán de mostrarlo todo, lo hace invisible. Borges lo corta, lo fragmenta, lo detalla azarosamente ${ }^{31}$. Así podemos verlo.

En el mismo libro sobre Eisenstein, Shklovski cuenta que las películas europeas en Afganistán se veían acompañadas por los comentarios de un narrador, cuyo relato sustituía el acompañamiento del piano, e indicaba qué debía verse de las imágenes: "el comentarista decía: «Ustedes ven a los europeos; son personas cómicas y malas, las mujeres traicionan a sus esposos, los esposos solo piensan en dinero, sus amigos les son infieles»" 32 . Del mismo modo analiza y distingue al cine de

\footnotetext{
30 Ranciere, J., El espectador emancipado (trad. Ariel Dillon), Buenos Aires, Manantial, 2010, p. 19. 31 "La función del detalle en una economía policial es únicamente la de dar una clave para llegar al nombre, y esto es lo que ocurre en todos los iconógrafos. Mientras que en el tipo de trabajo que yo defiendo, una vez que tienes esa clave, la utilizas para abrir una puerta que va a dar a otra puerta, que a su vez va a dar a otra, en una red interminable: Borges, arborescencia, árbol, ramas, tramas... es lo que Lacan llama la cadena significante”. Didi-Huberman, «Un conocimiento por el montaje», entrevista con Pedro G. Romero disponible en: http://www.circulobellasartes.com.
}

32 Shklovski 2009, op. cit. (nota 3), p. 212. 
argumento del Cine-Verdad de Vertov ${ }^{33}$. Los innumerables versos del poema de Daneri, acomodados al parecer cronológicamente (respeta el paso de Homero a Hesíodo), y cuidadosamente ordenados (empieza por "el principio", Canto Augural, Canto Prologal o simplemente Canto-Prólogo), están a su vez continuados indefectiblemente por la explicación que Carlos Argentino hace de ellos, la cual se nos presenta como parte de la obra e intenta determinar lo que se debe ver en los versos. Esto es finalmente advertido por el narrador: "comprendí que el trabajo del poeta no estaba en la poesía; estaba en la invención de razones para que la poesía fuera admirable" (¿cuál es la obra?, ¿los versos o lo que se dice sobre ellos?, Daneri gana el Premio Nacional de Literatura, Borges se niega a hablar de los versos de Daneri a Álvaro para que los prologue....). Daneri explica la consecución de sus versos, las imágenes que usa como representación (no las expone para que su conjunto diga algo, él habla por ellas), sus versos métricos persiguen los metros del planeta: como un mapa de China del tamaño de China ${ }^{34}$, o el recuerdo de un día completo que lleva exactamente otro día completo de tiempo 35 . Daneri pretende transmitir un Aleph idéntico pero hecho de palabras. El proyecto de Daneri es escribir toda la redondez del planeta, sin cortes, sin edición, sin pausas. Podríamos pensar entonces que este primer testigo y escritor del aleph no utiliza al montaje como procedimiento. Contrariamente, la escritura de Borges del Aleph está presentada como un imposible, pues justamente la diacronía que exigen las palabras en el despliegue de sus letras ya desfiguran el instante eterno (si el oxímoron se me permite, como diría Borges) de la contemplación del Aleph. Habrá que renovar al lenguaje, torcerlo de su lógica, hacer que diga lo que no puede decir (algo que obsesionaba a Borges por cierto, poder nombrar lo imposible ${ }^{36}$ ). La descripción del Aleph se abre con un

33 "los integrantes del grupo Cine-Ojo (...) afirmaban que en lugar de las obras cinematográficas con argumento, debía hacerse un simple registro del hecho: el cine verdad". Ibidem, p. 152.

34 "En aquel imperio, el Arte de la Cartografía logró tal Perfección que el mapa de una sola Provincia ocupaba toda una Ciudad, y el mapa del Imperio, toda una Provincia. Con el tiempo, esos Mapas Desmesurados no satisficieron y los Colegios de Cartógrafos levantaron un Mapa del Imperio, que tenía el tamaño del Imperio y coincidía puntualmente con él”. (Borges, «Del rigor en la ciencia», en Obras Completas II (1952-1972), Buenos Aires, Emecé, 2010, p. 339).

35 “....dos o tres veces había reconstruido un día entero, no había dudado nunca, pero cada reconstrucción había requerido un día entero" (Borges, «Funes el memorioso», en Ficciones, Buenos Aires, Emecé, 2000, p. 168).

36 Este movimiento ya lo podíamos ver en "Funes el memorioso" donde este personaje no puede recordar sino las particularidades de las presencias de las cosas sin llegar a su signo o su concepto abstracto ("No solo le costaba comprender que el símbolo genérico perro abarcara tantos individuos dispares de diversos tamaños y diversa forma; le molestaba que el perro de las tres de las tres y catorce (visto de perfil) tuviera el mismo nombre que el perro de las tres y cuarto (visto de frente)". (Ibidem, p. 171). Otro ejemplo lo encontramos en el prólogo que Foucault escribe a Las palabras y las cosas (Buenos Aires, Siglo XXI, 2008) donde cita al propio Borges para llevar al extremo esta problematización entre la palabra y la imagen, y el momento en que la palabra -sin dejar de serlo- se inviste de algo de la 
"lamento" respecto al lenguaje: "empieza aquí mi desesperación de escritor. Todo lenguaje es un alfabeto de símbolos (...) ¿cómo transmitir a los otros el infinito Aleph, que mi temerosa memoria apenas abarca?". Contrariamente a Daneri que hace años escribe el Aleph, Borges ocupa dos páginas, recorta, combina, choca, edita, junta, y finaliza.

... vi convexos desiertos ecuatoriales y cada uno de sus granos de arena, vi en Inverness a una mujer que no olvidaré, vi la violenta cabellera, el altivo cuerpo, vi un cáncer en el pecho, vi un círculo de tierra seca en una vereda, donde antes hubo un árbol, vi una quinta en Adrogué, un ejemplar de la primera versión inglesa....37

Se niega luego a "discutirlo" con Daneri. El Aleph es esa enumeración errática de fragmentos no ordenados. Entonces, de la "línea de montaje" 38 al trabajo con el montaje como procedimiento, creación con la que es posible, tal vez, la enumeración de un conjunto infinito y simultáneo. Por ejemplo, la figura del oxímoron tan utilizada por Borges ( $¡$ el lector ciego!) en toda su obra opera con el montaje como creación: dos términos contrapuestos que generan un sentido nuevo en su vínculo. La convivencia en el encuentro de opuestos que se enciman, relacionan y multiplican. Beatriz es definida a través de este procedimiento por su "graciosa torpeza", así también "la ilegible biblioteca" donde Daneri trabajaba. En estos casos operan, mediante el montaje, dos términos que no estaban relacionados y asumen una posición diferente. Las imágenes o palabras "hablan más".

Borges reniega de la literatura ("Quizás los dioses no me negarían un hallazgo de una imagen equivalente pero este informe quedaría contaminado de literatura, de falsedad"39), pero escribe literatura. El Aleph no se puede transmitir con palabras, pero es con palabras que el Aleph existe (como en Freud, el relato del sueño es el sueño). Entonces, insistir en lo imposible de nombrar y nombrarlo, las palabras no reflejan pero muestran, como los espejos del Aleph. El lenguaje es un modo de percibir el mundo, no lo refleja. Lo organiza. No es comunicación, por eso nombrar lo imposible lo hace posible, por eso no explicar, no discutir el Aleph con Daneri.

imagen, se detiene en sí misma, quiebra la relación con las cosas logrando nombrar algo imposible. Como dice Foucault, hay momentos en que el lenguaje en Borges pierde lo "común" del lugar y del nombre. El lenguaje olvida su condición de abstraer y generalizar, como el sistema de numeración inventado por Funes. “...los animales si dividen en a] pertenecientes al Emperador, b]embalsamados, c] amaestrados, d] lechones, e] sirenas, f] fabulosos, g] perros sueltos, h] incluidos en esta clasificación, i]que se agitan como locos, j] innumerables k]dibujados con un pincel muy finísimo de pelo de camello, 1] etcétera, m] que acaban de romper el jarrón, n] que de lejos parecen moscas".

37 Borges 2000, op. cit. (nota 1), pp. 259, 260.

38 "lo decisivo no es la prosecución de conocimiento a conocimiento [como hila Daneri sus versos]. El salto es la marca imperceptible de autenticidad que los distingue de las mercancías en serie elaboradas según un patrón”. Benjamin 1987, op.cit. (nota 15), p. 150.

39 Borges 2000, op.cit. (nota 1), p. 259. 
Lo que más tarde Serguei Mijailovich Eisenstein denominará «teoría del montaje» (...) era el modo de crear un sistema de lenguaje literario, teatral o cinematográfico con su propia semántica. No eran las palabras, sino sus combinaciones, lo que creaba una forma. No se indica en el guión cómo debe comprenderse todo esto. Pero se muestra en la película. 40

Una otra manera determinada de organizar el saber de las imágenes sin anquilosarlo41 (Daneri), sin convertirlas en signo cristalizado (Borges, en su enumeración no usa "la" o "el" sino "un") ni mercadería (como afiches de publicidad). Una escritura de lo imposible. Una posible ordenación sensible del mundo, unas posiblesotras relaciones en la formación de conocimiento del mundo (como el oxímoron) como la matemática elaboró una teoría de los conjuntos para hablar de los infinitos infinitos (y ahí, bueno, "El jardín de los senderos que se bifurcan”).

Didi-Huberman analiza la producción artística como un trabajo de montaje en el que reordenar las cosas, los lugares y el tiempo. Elige a la mesa como el espacio para pensar el trabajo artístico por ser un plano en el que cosas distintas pueden combinarse de distinta manera. En este cuento de Borges aparecen dispuestos en un mismo plano, el de la escritura, elementos, términos, imágenes, (el oxímoron, una larga frase, una enumeración caótica, azarosa, errática), que ni espacial ni temporalmente podrían relacionarse, pero que lo hacen en esa escritura y postulan una nueva forma de inteligibilidad del mundo. Mapas y laberintos. Problematizar la capacidad representativa del lenguaje, hacerlo imagen, no desde un registro visual (como la poesía concreta, los caligramas, etc.), sino dentro del orden mismo de escritura 42 . $\mathrm{Su}$ modo de llevar algo del orden de la imagen a la palabra es el operar por montaje, tanto en la apertura del imposible de escribir lo simultáneo ("lo que mis ojos vieron fue simultáneo"), como en las inserciones en su escritura de elementos heterogéneos, operaciones conceptuales que aparecen desde el encuentro de términos opuestos; hasta sus comentarios, citas y referencias a su biblioteca infinita, la traducción y el apócrifo. Intervenciones todas que abren, extienden, ramifican, multi-

\footnotetext{
40 Shklovski 2009, op. cit. (nota 3), p. 160.

41 Según WordReference: "atrofiar, baldar, inmovilizar, paralizar, impedir" (consultado en: http://www.wordreference.com/es/) y el Diccionario de la Real Academia Española: "Paralizarse, detenerse en su evolución" (consultado en: http://www.rae.es/).

42 Pero compartiendo con la poesía concreta su propuesta de percepción ideográfica frente a la diacronía del discurso, como Arturo Carrera señala sobre el grupo brasilero Noigandress: “...opuso a los esquemas analítico-discursivos de la sintaxis tradicional, su concepción antidiscursiva del poema y de la «poesía» que abdicó ante su esclerosado espectro. Los primeros trabajos teóricos -y aún los últimos-, repasan sincrónicamente, ora los manifiestos futuristas italianos, ora las primeras declaraciones de Apollinaire sobre la ideografía y la antilógica gramatical: «...poema ideográfico». Revolución: porque es necesario que nuestra inteligencia se habitúe a comprender sintético ideográficamente en lugar de analítico-discursivamente" («Los inventores visuales», Diario La Opinión Cultural, Buenos Aires, 5 de febrero de 1978).
} 
plican. Como en el retrato de Beatriz, nombra y combina fragmentos, ata detalles. El montaje aparece en tanto corte, combinación y reordenamiento. Laberintos y mapas. De este modo llego a concebir la escritura borgeana como un atlas.

La escalera del sótano es empinada, mis tíos me tenían prohibido el descenso, pero alguien dijo que había un mundo en el sótano. 43

Pregunto, entonces, a Borges y a Daneri: ¿Cómo llevar el mundo a cuestas? Si no hay palabras de todo (como persigue Daneri), ni absolutización del silencio, ("algo, sin embargo, recogeré", dice Borges y se larga a nombrar el Aleph), hay palabras "pese a todo", concluimos. En un primer momento, encontramos la imagen y la palabra donde Beatriz se contenía, ahora tenemos algunas palabras que recuperan el movimiento mostrativo del Aleph, no todo lo que mostró sino la simultaneidad, el con-junto, la yuxtaposición sin superposición, el vínculo. Y el Aleph puede decirse de algún modo. Para lo cual se trabaja con montaje como procedimiento, no siendo funcional a lo idéntico, llevando un mundo del tamaño del mundo, sino interviniendo activamente como procedimiento de construcción. Nombrar el mundo por lo particular, y en ese fragmento, encerrarlo, pues es un vestigio lo que decimos del todo. La escritura en Daneri es repetitiva, la imagen o el verso repiten el mundo ("el niño está en el sótano, revelando fotografías"), lee y así repite lo escrito, explica y vuelve a repetir lo escrito; la escritura de Borges es creativa en tanto no puede decir exactamente lo que vio, en tanto lo modifica y rearma en un trozo de su acontecer disperso y simultaneo, y así se corre de vouyeur a participante.

Casi en el final de su larga vida, en 1984 Borges publica Atlas, un libro "sabiamente caótico", según sus propias palabras. En el prólogo aclara que no se trata de textos ilustrados por fotografías, ni de fotografías explicadas por un epígrafe, si no que "cada título es una unidad, hecha de imágenes y de palabras" 44 . El libro en su totalidad termina siendo una colección de pequeñas entradas, textos breves y poemas (solo la primera edición incluía fotografías), que no delinean un itinerario ni una ruta con principio y fin, que tampoco arman un recorrido cronológico ni lo que podría ser una unidad de tiempo. Es, como el Aleph escrito por el personaje Borges del cuento, un conjunto de retazos, jirones, momentos aislados, apuntes vitales desde varios puntos de vista que rozan los espacios visitados para terminar, como dice el escritor, con la certidumbre casi total de la propia ignorancia.

...una sola imagen - al igual que un solo gesto-, reúne en sí misma varios tiempos heterogéneos. De manera que para historizar las imágenes hay que crear un archivo que no

43 Borges, op.cit. (nota 1), p. 256.

44 Borges, J. L., Obras completas, Tomo III, Buenos Aires, Emecé, 2011, p. 695. 
puede organizarse como un puro y simple relato, puesto que es algo fatalmente más complejo. (...) Me parece muy importante que en un momento en el que la historia de Europa está siendo sacudida completamente, haya pensadores y artistas que se replantean la historia en términos de estallido y reconstrucción, que es a lo que podemos llamar-asi lo llamo yo-conocimiento por el montaje. ${ }^{45}$

45 Didi-Huberman, op. cit. (nota 31). 